\title{
INTEGRATION OF CHARACTER VALUES IN LEARNING AKIDAH AKHLAK AT MADRASAH IBTIDAIYAH INTEGRAL AL UKHUWWAH BANJANG
}

\author{
By: \\ Husin, M.Pd \\ Lecturer, Amuntai College of Koran Studies (STIQ), South Kalimantan \\ hafizhhusinsungkar@gmail.com
}

\begin{abstract}
This study aims to determine the integration of character values in learning Akidah Akhlak at Madrasah Ibtidaiyah Al Ukhuwwah, Banjang District, Hulu Sungai Utara Regency and how it is implemented in children's daily lives.This study used a qualitative method with the type of narrative research and data collection through observation, document review and interviews with school principals and teachers of Akidah Akhlak subjects.In the interview process, the researcher also conducted a depth interview on the important points obtained in the initial interview process. In the cognitive aspect, teacher assessments include oral tests, practice scores, assignments, homework (PR) and daily test scores, on the psychomotor aspect, teacher assessments include students' skills to demonstrate the value of caring for others in front of the class, on the affective aspect, teachers assess students who actively participate in class discussions. This research contributes to the study of the integration of character values in various lessons so that in its implementation it can be used as an example or modified according to the needs of the learning process that has been designed by the teacher and adapted to the established learning model and strategy.

Keywords: Akidah Akhlak, Cognitive, Affective, Psychomotor.
\end{abstract}

\section{INTRODUCTION}

Character education has been widely discussed among the general public and the world of education since 2010. The government, through the Ministry of National Education, has launched the implementation of character education for all levels of education, from primary schools to tertiary institutions. Character education is a planned effort to make students recognize, care for and internalize values so that students behave as human beings. ${ }^{1}$ Character education is used as the basis for realizing the vision of national

\footnotetext{
${ }^{1}$ Muchlas Samani dan Hariyanto, Konsep dan Model Pendidikan Karakter, (Bandung: Remaja Rosdakarya,
} 2013), cet-3, h. 46 
development, namely realizing a society with noble, moral, ethical, cultured and civilized characters based on the Pancasila philosophy. In addition, character education is an effort to support the realization of ideals as mandated in Pancasila and the Preamble of the 1945 Constitution.

Education in Indonesia has actually been taught about character, which is better known as a positive character, which can be seen in a person's behavior and has been taught by teachers and parents, but this behavior only exists in some people who uphold certain values. ${ }^{2}$ In its implementation, it involves three components that are interrelated with each other, namely: school (campus), family and community. ${ }^{3}$ Character education in schools can be pursued in the form of culturing unique daily activities in accordance with the vision and mission of the school. Whereas in the classroom, character education can be integrated (combined or combined) in the learning of each subject. Character education aims to improve the quality of education administration and outcomes that lead to the achievement of character building and noble ethics of students as a whole, integrated and balanced according to the competency standards of graduates. ${ }^{4}$ A good teacher is expected to be able to create opportunities for children to satisfy their curiosity, to use all senses in exploration, to expand their minds, and develop their potential. Because in reality there are not a few teachers who do not know the potential of their students. This ignorance of course affects the patterns of approach and learning undertaken. ${ }^{5}$

The integration of character education in learning involves various learning components both strategies, materials and evaluation systems. Character education in learning Akidah Akhlak can also be done through core competencies, learning objectives, and learning methods used by teachers of Akidah Akhlak subjects. ${ }^{6}$ Careful planning is also needed so that character education can be achieved according to goals. However, the fact is that the tendency of the learning process in the classroom does not indicate a character education. This can be seen from the planning design that still tends to be teacher-centered, the teaching and learning activities that occur are not contextual to children's lives and final evaluations are rarely carried out. ${ }^{7}$ The moral curriculum and character building both have the same goal, namely wanting to

\footnotetext{
${ }^{2}$ Wijaya, Darma, Hadi Wibowo, Dedi Supriadi, and Sopyan Sopyan. "Pendidikan Karakter Dalam Perspektif Islam." Jurnal Akrab Juara 5, no. 4 (2020): h. 189.

${ }^{3}$ Muslich Masnur, Pendidikan Karakter Menjawab Tantangan Krisis Multidimensional, (Jakarta: Bumi Aksara, 2011), h. 93

${ }^{4}$ M. Mahbubi, Pendidikan karakter Implementasi Aswaja sebagai Nilai Pendidikan Karakter, (Yogyakarta: Pustaka Ilmu, 2012),h. 42

${ }^{5}$ Azhar, Choral, and Pizza Sa'idah. "Studi analisis upaya guru Akidah Akhlak dalam mengembangkan potensi nilai moral peserta didik di MI Kabupaten Demak." Al-Ta'dib 10, no. 2 (2017) : h. 77.

${ }^{6}$ Mulia, Harpan Reski. "Integrasi Pendidikan Karakter dalam Pembelajaran Akidah Akhlak." TADRIS: Jurnal

Pendidikan Islam 15, no. 1 (2020): h. 118.

${ }^{7}$ Dharma Kesuma, dkk, Pendidikan karakter Kajian Teori dan Praktik di Sekolah, (Bandung: PT Remaja Rosdakarya, 2012), h.109
} 
bring children closer to God, be human, live socially and respect each other. Without morals, children will not have good character, so every character must be accompanied by morals. ${ }^{8}$

The challenge faced in learning Akidah Akhlak is how to implement it, not only teaching knowledge about religion but how to direct students to have the quality of faith, piety and noble morals. ${ }^{9}$ Substantially, the Akidah Akhlak subject has a contribution in providing motivation to students to practice the values of religious beliefs (tauhid) and akhlaqul karimah in everyday life. ${ }^{10}$ Therefore, learning Akidah Akhlak in addition to requiring students to be able to master knowledge and skills about Akidah Akhlak also aims to develop the character of students. The implementation of character education in Akidah Akhlak learning can certainly be expected to be different from the implementation of character education in general material because in Akidah Akhlak there are various kinds of tauhid and moral values in everyday life.

The Curriculum Center for the Research and Development Agency of the Ministry of National Education in its publication entitled "Guidelines for the Implementation of Character Education" states the objectives and functions of character education, in connection with that a number of character-forming values have been identified which are the results of empirical studies of the center of the curriculum, namely the values that are sourced from religion, Pancasila, culture and national education goals, these values are "Religious, Honest, Tolerance, Discipline, Hard Work, Creative, Independent, Democratic, Curiosity, National Spirit, Love the Fatherland, Respect for achievement, Communicative, Love peace, Like to read, Care about social, and the environment, and responsibility ". ${ }^{11}$

These values can be cultivated to students who will ultimately reflect the life of the Indonesian nation. Therefore, schools have a large role as the center of culture through the development of school culture.

\section{RESEARCH METHODS}

The research method used in this study uses qualitative methods with the type of narrative research. The research procedure carried out will produce descriptive data in the form of written or spoken words from people and observable behavior. ${ }^{12}$

The qualitative approach emphasizes the meaning, reasoning, the definition of a certain situation (in a certain context), and examines more things related to everyday life. ${ }^{13}$ In a qualitative approach, the

\footnotetext{
${ }^{8}$ Fatmawati, Fatmawati, and Yusrizal Yusrizal. "Peran Kurikulum Akhlak Dalam Pembentukan Karakter Di Sekolah Alam Sou Parung Bogor." Jurnal Tematik 10, no. 2 (2020): h. 80.

9 Suryawati, Dewi Prasari. "Implementasi Pembelajaran Akidah Akhlak Terhadap Pembentukan Karakter Siswa di MTs Negeri Semanu Gunungkidul." Jurnal Pendidikan Madrasah 1, no. 2 (2016): h. 310.

${ }^{10}$ Achmad Lutfi, Pembelajaran Akidah Akhlak, (Jakarta: Direktorat Jenderal Pendidikan Islam, Kementerian Agama RI, 2012), h. 50

${ }_{11}$ Muchlas Samani dan Hariyanto, Konsep dan Model Pendidikan Karakter, (Bandung: Remaja Rosdakarya, 2013), cet-3, h. 9

${ }^{12}$ Lexy J. Moleong, MA, Metodologi Penelitian Kualitatif, (Bandung: PT Remaja Rosdakarya, 2009), h. 6
} 
Husin : Integration of Character Values in Learning Akidah Akhlak at Madrasah Ibtidaiyah Integral Al Ukhuwah Banjang

data is descriptive, meaning that the data can be categorized symptoms or in other forms, such as photos, documents and field notes when the research was carried out. ${ }^{14}$ This study was used to describe everything related to the integration of character values in learning Akidah Akhlak at MI Integral Al Ukhuwwah.

\section{RESEARCH RESULTS AND DISCUSSION}

This research was conducted at Madrasah Ibtidaiyah Integral Al Ukhuwah, Banjang district, Hulu Sungai Utara regency, South Kalimantan province. As a new school that was established in 2018, this madrasah is one of the favorite madrasas and its development is quite rapid, both in terms of increasing the number of students and the number of buildings or infrastructure.

The word integration in the Big Indonesian Dictionary, is "Blending until it becomes a complete or unified whole"15. Meanwhile, integrating is "combining; unite "16. The integration in this research is an amalgamation or combination of character values with learning Akidah Akhlak Character values consist of two words, namely the word value and character. The word value in the Big Indonesian Dictionary has many meanings including "The attributes (things) that are important or useful for humanity, something that perfects humans according to their essence". ${ }^{17}$ Meanwhile, the character according to WJS Poerwadarminta is "the character, character, psychiatric traits, morals or character that distinguishes a person from another". ${ }^{18}$ In a simple sense, Islamic character can be defined as a character that comes from Islamic teachings or character that is Islamic, in which the word Islamic is a characteristic for morals itself. Therefore, the Islamic character of actions is carried out easily and relies on Islamic teachings. ${ }^{19}$

The results showed that Madrasah Ibtidaiyah Al Ukhuwwah was one of the Islamic schools that had implemented an integrated education program. The way they do this is by integrating Islamic values into every subject that is carried out. The subjects in this study were the Akidah Akhlak teachers at Madrasah Ibtidaiyah Al Ukhuwwah. Meanwhile, the object of this research is the integration of character values in

13 Jamal Ma'mur Asmani, Tuntunan Lengkap Metodologi Praktis Penelitian Pendidikan: Buku Super Praktis Penelitian Pendidikan Modern Terkini, (Jogjakarta: DIVA Press, 2011), h. 108

14 Jamal Ma'mur Asmani, Tuntunan Lengkap Metodologi Praktis Penelitian Pendidikan: Buku Super Praktis Penelitian Pendidikan Modern Terkini, (Jogjakarta: DIVA Press, 2011), h. 110

${ }^{15}$ Tim Penyusun Kamus Pusat Bahasa, Kamus Besar Bahasa Indonesia, (Jakarta: Balai Pustaka, 2005), ed-3, cet-3, h. 437

${ }^{16}$ Tim Penyusun Kamus Pusat Bahasa, Kamus Besar Bahasa Indonesia, (Jakarta: Balai Pustaka, 2005), ed-3, cet-3, h. 437

${ }^{17}$ Tim Penyusun Kamus Pusat Bahasa, Kamus Besar Bahasa Indonesia, (Jakarta: Balai Pustaka, 2005), ed-3, cet-3, h.783

${ }^{18}$ Departemen Pendidikan Nasional, Kamus Umum Bahasa Indonesia, (Jakarta: Balai Pustaka, 2010), ed-3, cet-7, h. 521

${ }^{19}$ Basuki, Danang Dwi, and Hari Febriansyah. "Pembentukan Karakter Islami melalui Pengembangan Mata Pelajaran Akidah Akhlak di Madrasah Aliyah An-Najah Bekasi." Jurnal Intelektual: Jurnal Pendidikan dan Studi Keislaman 10, no. 2 (2020): h. 123. 
learning Akidah Akhlak. Therefore, to obtain the necessary data, the researcher observed the implementation of Akidah Akhlak learning which included planning, implementing and evaluating learning.

The results showed that the integration of character values in learning Akidah Akhlak at Madrasah Ibtidaiyah teachers had planned the integration of character values expected in students in the lesson plan (RPP), then the teacher integrated character values in every learning activity through providing understanding, habituation. and exemplary to students based on exploration, elaboration and confirmation activities. Then the teacher makes an assessment in the learning process including cognitive aspects, namely by oral tests, exercise scores, assignments, homework and daily test scores. In the psychomotor aspect, students' skills demonstrate the value of caring for others in front of the class. In the affective aspect, namely by assessing students who actively participate in class discussions.

Based on observations in the syllabus and lesson plans, on the aspects of the method, learning steps and assessment, the researcher found character development efforts, but on the indicators and learning objectives made by the teacher, the researcher did not find the development of the characters to be implanted. Based on the learning activities planned by the teacher in the class lesson plans, the activities in the learning steps are activities that can develop characters, including preliminary, core and closing activities. In the lesson plans made by teachers in the Akidah Akhlak study, the planned assessment includes 3 aspects, namely cognitive, psychomotor and affective aspects. In the cognitive aspect, he set an assessment with students working on worksheets (student worksheets), on the psychomotor aspect,

At the implementation stage, the researcher conducted 3 class observations related to the integration of religious character values, discipline, tolerance, independence, honesty, confidence, cooperation, and creativity in learning Akidah Akhlak, especially in the material "Asmaul Husna" through 4 activities, namely pre-learning activities, preliminary activities, core activities and closing activities. The following is a description of the process of implementing the integration of character values in learning Akidah Akhlak.

1) Pre-learning activities

Pre-learning activities are activities carried out by teachers andstudents before learning begins. At MI Al Ukhuwwah there are several rules before learning begins, namely that the shoes of teachers and students are placed on the provided shelves and are not allowed to wear them in the study room (class) or around them. In addition, every time you start learning (in each subject), all students in the class are prepared to greet and recite prayers led by the ustadzah in turns every day. Likewise in the closing activity, all class students were prepared to end the lesson by greeting and reciting prayers and led by the ustadzah in turns every day, it was hoped that a disciplined and religious attitude would emerge in students. Therefore, researchers do not only observe the activities of the predecessors, the core and the closing ones. 


\section{2) Preliminary activities}

Based on the results of interviews with teachers of Akidah Akhlak subjects, character education that is integrated in the preliminary activities is through activities to accustom students to having the desired character and with the exemplary attitude of the teacher. And based on the results of observations during the study, the teacher:

a) Make it a habit to check on students and don't forget to ask how students are. From the teacher's attendance activities, students are accustomed to having a disciplined character. Meanwhile, from the activity of asking for news, the teacher provides an example for students to have a caring character for others.

b) Condition the class so that students are ready to carry out learning. This is done to accustom students to have a disciplined character.

c) Ask for materials at the previous meeting. With this activity, the teacher indirectly accustoms students to be able to think creatively.

d) Describe the scope of material to be studied. The teacher explained that at this meeting he would discuss the Asmaul Husna material.

3) Core activities

a) Exploration

1) The teacher engages students in finding extensive information about the topic / theme of the material to be studied, by asking students. Based on the results of observations, after the teacher explained that the meeting this time would discuss Asmaul Husna, then the students were asked who already knew the meaning of Asmaul Husna. By asking students about the material to be studied, the teacher indirectly accuses students to be independent and think logically.

2) The teacher facilitates interaction between students, students and teachers, the environment, and other learning resources and involves students actively in every learning activity. Based on the results of observations, the teacher first asks questions about Asmaul Husna to students, if one of the students answers, but the answer is not perfect, the teacher gives the other students the opportunity to answer as well until the answer given by the student is considered correct. And the teacher asks students to listen to their friends' opinions. From this activity, the teacher accustoms students to have independent character, self-confidence, cooperation and mutual respect. After several students answered and expressed their opinion, after that the teacher gave a conclusion on all the students' answers. 
b) Elaboration

The teacher invites students to read, memorize or write related to the material being studied. During the learning process to memorize, the teacher asks students to read first, then memorize it, starting classically, in groups and finally individually.

When the learning process takes place there is a variety of student activity, some are passive, some are active. If given questions, often active students want to continue answering and don't give other friends a chance. So the teacher advises that there are many learning in the class, there are friends who want to get the opportunity to answer questions too. With this explanation or understanding, students are expected to have a sense of tolerance and care for each other. Conversely, students who are considered quiet or passive are motivated so that they are more confident and able to cooperate with their peers.

Character values that are indirectly integrated by the teacher through elaboration activities include:

1. Love knowledge, creative and logical (from the teacher's activities asking students to read first then memorize and listen to explanations from the teacher about the meaning, as well as the content contained in the subject matter).

2. Confidence, cooperation and mutual respect (from quiz games to training students in memorizing and writing).

3. Creative (from activities to package explanations about Asmaul Husna).

4. Tolerance (from the explanation the teacher gives when there are students who want to keep answering).

c) Confirmation

In the confirmation stage, students are given the opportunity to reflect on various skills that have been learned, ask questions about things that are not known by students, and provide reinforcement for various skills students already have. The character values that are indirectly integrated by the teacher through the above confirmation activities are:

1. Confident and honest (from the activity to give a final explanation of the task).

2. Understand one's own strengths and weaknesses (from the activity of providing reinforcement for the various skills students already have).

3. Critical thinking (from asking and answering questions about things that are not known by students).

d) Closing Activities

Based on the results of observations that have been made, closing activities are usually filled with: 
a) Invite students to make conclusions from what they have learned. From this activity students are accustomed to have an independent character and be able to work together with their friends.

b) Conduct an assessment of activities that have been carried out. From this activity students are accustomed to having an honest character, knowing their own shortcomings and strengths.

c) Provide several motivational messages that are usually inserted with character values contained in the content of learning materials that have taken place.

In closing activities that coincide with recess hours or go home from school, teacher habits are:

a) Provide questions related to the material that has been studied. Students who can answer in advance are given the opportunity to rest or go home first. This activity indirectly accustoms students to always think, be creative and respect themselves and others.

b) When the class ends, the teacher and students pray together. By being accustomed to praying, it is hoped that a religious attitude will arise in students.

c) Or students are asked to sit neatly, the neatest can go home first. This activity indirectly accustoms students to discipline and respect for themselves and others.

d) Then the students who can answer the questions or who are the neatest, are welcome to kiss the teacher's hand and leave the classroom first. Through this activity students are accustomed to have the character of courtesy and respect for teachers or elders.

c. Evaluation

Evaluation of the integration of character values in learning Akidah Akhlak includes how to evaluate student character by the teacher, student character results and follow-up on student character.

Based on the observations made by the researcher, it was found that the assessment carried out by the teacher in the Akidah Akhlak study area included cognitive, psychomotor and affective aspects. In the cognitive aspect, teacher assessments include oral tests, practice scores, assignments, homework (PR) and daily test scores. From this activity students are accustomed to have an independent and honest character. In the psychomotor aspect, teacher assessment includes students' skills to demonstrate the value of caring for others in front of the class. From this activity students are accustomed to have a confident character. And finally in the affective aspect, the teacher assesses students who actively participate in class discussions. From this activity students are accustomed to having a creative character and collaboration. With regard to evaluating student character, The technique of evaluating character values in learning Akidah Akhlak is carried out through teacher observations of the state of student behavior from day to day. Every day the teacher also always attend students crafts in carrying out the noon prayers in congregation. In addition, there is a liaison 
Husin : Integration of Character Values in Learning Akidah Akhlak at Madrasah Ibtidaiyah Integral Al Ukhuwah Banjang

book for teachers and guardians to assess the craft in carrying out prayers at home. It's just that teachers do not have standardized indicators of the success of character education.

\section{CONCLUSION}

Based on the results of the research that has been described previously, it can be concluded that the assessment carried out by teachers in the Akidah Akhlak study area includes cognitive, psychomotor and affective aspects. In the cognitive aspect, teacher assessments include oral tests, practice scores, assignments, homework (PR) and daily test scores. From this activity students are accustomed to have an independent and honest character. In the psychomotor aspect, teacher assessment includes the skills of students demonstrating the value of caring for others in front of the class. From this activity students are accustomed to have a confident character. And finally in the affective aspect, the teacher assesses students who actively participate in class discussions. From this activity students are accustomed to having a creative character and collaboration. With regard to evaluating student character, The technique of evaluating character values in learning Akidah Akhlak is carried out through teacher observations of the state of student behavior from day to day. Every day the teacher also always attend students crafts in carrying out the noon prayers in congregation. In addition, there is a liaison book for teachers and guardians of students to assess the craft in carrying out prayers at home. It's just that teachers do not have standardized indicators of the success of character education.

\section{REFERENCES}

Asmani, Jamal Ma'mur, Tuntunan Lengkap Metodologi Praktis Penelitian Pendidikan: Buku Super Praktis Penelitian Pendidikan Modern Terkini, Jogjakarta: DIVA Press. 2011

Azhar, Khoirul, and Izzah Sa’idah. "Studi analisis upaya guru Akidah Akhlak dalam mengembangkan potensi nilai moral peserta didik di MI Kabupaten Demak." Al-Ta'dib 10, no. 2 (2017)

Basuki, Danang Dwi, and Hari Febriansyah. "Pembentukan Karakter Islami melalui Pengembangan Mata Pelajaran Akidah Akhlak di Madrasah Aliyah An-Najah Bekasi." Jurnal Intelektual: Jurnal Pendidikan dan Studi Keislaman 10, no. 2 (2020)

Departemen Pendidikan Nasional, Kamus Umum Bahasa Indonesia, Jakarta: Balai Pustaka. 2010

Fatmawati, Fatmawati, and Yusrizal Yusrizal. "Peran Kurikulum Akhlak Dalam Pembentukan Karakter Di Sekolah Alam Sou Parung Bogor." Jurnal Tematik 10, no. 2 (2020)

Kesuma, Dharma, dkk, Pendidikan karakter Kajian Teori dan Praktik di Sekolah, Bandung: PT Remaja Rosdakarya. 2012

Lutfi, Achmad, Pembelajaran Akidah Akhlak, Jakarta: Direktorat Jenderal Pendidikan Islam, Kementerian Agama RI. 2012

Mahbubi, M.,Pendidikan karakter Implementasi Aswaja sebagai Nilai Pendidikan Karakter, Yogyakarta: Pustaka Ilmu. 2012 
Husin : Integration of Character Values in Learning Akidah Akhlak at Madrasah Ibtidaiyah Integral Al Ukhuwah Banjang

Masnur, Muslich Pendidikan Karakter Menjawab Tantangan Krisis Multidimensional, Jakarta: Bumi Aksara. 2011

Moleong, Lexy J., Metodologi Penelitian Kualitatif, Bandung: PT Remaja Rosdakarya. 2009

Mulia, Harpan Reski. "Integrasi Pendidikan Karakter dalam Pembelajaran Akidah Akhlak." TADRIS: Jurnal Pendidikan Islam 15, no. 1 (2020)

Samani, Muchlas dan Hariyanto, Konsep dan Model Pendidikan Karakter, Bandung: Remaja Rosdakarya. 2013

Suryawati, Dewi Prasari. "Implementasi Pembelajaran Akidah Akhlak Terhadap Pembentukan Karakter Siswa di MTs Negeri Semanu Gunungkidul." Jurnal Pendidikan Madrasah 1, no. 2 (2016)

Tim Penyusun Kamus Pusat Bahasa, Kamus Besar Bahasa Indonesia, Jakarta: Balai Pustaka. 2005

Wijaya, Darma, Hadi Wibowo, Dedi Supriadi, and Sopyan Sopyan. "Pendidikan Karakter Dalam Perspektif Islam." Jurnal Akrab Juara 5, no. 4 (2020) 